\title{
Pengaruh ukuran perusahaan, bid ask spread, dan volume perdagangan terhadap price reversal
}

\author{
Flora Sianipar*, Riswan, \& Ekaningtyas Widiastuti \\ Fakultas Ekonomi dan Bisnis, Universitas Jenderal Soedirman, Purwokerto, Indonesia \\ *Email of corresponding author: floraflorav@gmail.com
}

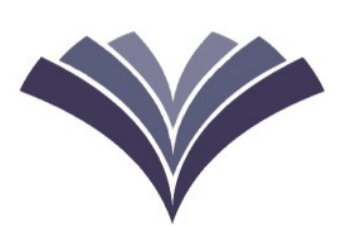

Performance

Vol. 24 No. 1, 2017

pp. 8-12

Published by Faculty of Economics and Business Jenderal Soedirman University on 2 January 2017

\section{DOI:}

10.20884/1.performance. 2017.24.1.312

ISSN:

1829-6467 (Print) 2615-8094 (Online)

How to cite this article: Sianipar, F., Riswan, \& Widiastuti, E. (2017). Pengaruh ukuran perusahaan, bid ask spread, dan volume perdagangan terhadap price reversal. Performance, 24(1), 8-12. https://doi.org/10.20884 /1.performance.2017.24.1 .312

This article is available at: http://jos.unsoed.ac.id/in dex.php/performance/ar ticle/view/312

or scan this with your mobile device

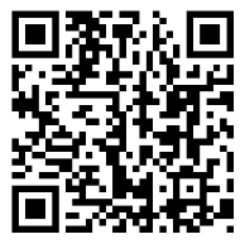

Received 22 November 2016 Revised 6 December 2016 Accepted 20 December 2016

\section{Abstrak}

Tujuan: "Pengaruh Ukuran Perusahaan, Bid Ask Spread, dan Volume Perdagangan terhadap Harga Reversal" adalah penelitian yang bertujuan untuk menganalisis faktor-faktor yang mempengaruhi pembalikan harga pada perusahaan yang terdaftar dalam Indeks LQ45 periode 8-16 November 2016.

Metodologi: Penelitian ini merupakan penelitian asosiatif untuk menentukan hubungan atau pengaruh antara dua atau lebih variabel. Populasi yang digunakan dalam penelitian ini adalah semua perusahaan yang terdaftar di Bursa Efek Indonesia selama periode penelitian. Metode pengumpulan data menggunakan purposive sampling. Data yang diperoleh dari metode purposive sampling adalah 44 perusahaan. Metode analisis yang digunakan dalam penelitian ini adalah regresi linier berganda. Pengujian hipotesis dengan menggunakan koefisien determinasi yang disesuaikan, uji t-statistik, dan uji f-statistik.

Hasil: Hasil penelitian menunjukkan bahwa ukuran perusahaan berpengaruh positif dan signifikan terhadap price reversal, bid ask spread berpengaruh positif dan signifikan terhadap price reversal, dan volume trading memiliki pengaruh positif dan signifikan terhadap price reversal.

Implikasi: Implikasi dari kesimpulan di atas adalah bahwa investor dapat memperhatikan faktor ukuran perusahaan, bid ask spread, dan volume perdagangan sebagai dasar pertimbangan untuk berdagang di bursa untuk mendapatkan pengembalian terbaik sesuai dengan kompensasi dari risiko yang mereka terima.

Kata kunci: ukuran perusahaan, bid ask spread, volume perdagangan, reversal harga.

\begin{abstract}
Purpose: "The Influence of Firm Size, Bid Ask Spread, and Trading Volume on Price Reversal" is a research that aims to analyze the factors that affect price reversal on companies listed in LQ45 Index in period of November 8 - November 16, 2016.

Methodology: This research is an associative study to determine the relationship or influence between two or more variables. The population used in this study was all companies listed in the Indonesia Stock Exchange during the study period. The method of collecting data used purposive sampling. Data obtained from purposive sampling method was 44 companies. Analysis method used in this research was multiple linear regression. Testing the hypothesis used the adjusted coefficient of determination, $t$-statistic test, and f-statistic test.

Findings: The result of this research shows that firm size has positive and significant effect to price reversal, bid ask spread has positive and significant effect to price reversal, and trading volume has positive and significant impact to price reversal.

Implications: The implications of the above conclusions are that investors can pay attention to the factor of firm size, bid ask spread, and trading volume as a basic for consideration to trade on the exchange to get the best return in accordance with the compensation of the risk that they received.
\end{abstract}

Keywords: firm size, bid ask spread, trading volume, price reversal.

\section{PENDAHULUAN}

Pasar modal adalah pasar untuk memperjualbelikan sekuritas yang umumnya memiliki umur lebih dari satu tahun, seperti saham dan obligasi (Tandelilin, 2010). Pasar modal secara umum dapat diartikan sebagai pasar yang memperjualbelikan produk yang bersifat abstrak (Susilawati, 2009). Sedangkan dalam bentuk konkritnya, produk yang diperjualbelikan di pasar modal berupa lembar surat berharga (Jogiyanto, 2008). Dengan adanya pasar modal, investor sebagai pihak yang memiliki kelebihan dana dapat menginvestasikan dananya pada berbagai sekuritas dengan harapan memperoleh return dari investasi tersebut. Di sisi lain, perusahaan sebagai pihak yang memerlukan dana dapat menggunakan dana tersebut untuk mengembangkan perusahaannya. Salah satu motivasi investor melakukan investasi di pasar modal adalah untuk memperoleh return yang optimal, yaitu return yang sesuai dengan kompensasi risiko yang diterima. Oleh 
karena itu, seorang investor perlu mengikuti perkembangan pasar dan melihat informasi yang relevan dengan dinamika harga saham. Informasi yang relevan tersebut merupakan hal yang penting bagi investor karena dengan informasi tersebut, investor dapat bereaksi untuk mencapai harga keseimbangan yang baru. Jika pasar bereaksi dengan cepat dan akurat untuk mencapai harga keseimbangan baru yang sepenuhnya mencerminkan informasi yang tersedia, maka kondisi pasar ini disebut dengan pasar efisien (Jogiyanto, 2008).

Konsep pasar modal yang efisien adalah ketika harga semua sekuritas yang diperdagangkan telah mencerminkan semua informasi yang tersedia. Dalam hal ini, informasi yang tersedia dapat berupa informasi di masa lalu maupun informasi saat ini serta informasi yang bersifat pendapat rasional yang beredar di pasar yang bisa mempengaruhi perubahan harga. Konsep pasar yang efisien menyiratkan adanya suatu proses penyesuaian harga sekuritas menuju harga keseimbangan yang baru sebagai respons atas informasi baru yang masuk ke pasar (Tandelilin, 2010). Namun, beberapa penelitian menunjukan bahwa terdapat penyimpangan yang terjadi pada efisiensi pasar seperti fenomena pembalikan harga (price reversal), yaitu fenomena perubahan arah harga saham setelah terjadinya suatu perubahan besar dalam harga saham tertentu, baik berupa kenaikan maupun penurunan harga saham (Cleary dan Jones, 2011). Penelitian mengenai pembalikan harga saham (price reversal) tersebut pertama kali ditemukan oleh De Bondt dan Thaler pada tahun 1985. Hasil penelitian mereka menyatakan bahwa saham yang berkinerja baik (winner) pada periode berikutnya berkinerja buruk dengan abnormal return negatif dan sebaliknya saham yang berkinerja buruk (loser) pada periode berikutnya berkinerja baik dengan abnormal return positif. Hal ini membuat adanya fenomena pembalikan harga pada periode selanjutnya. Namun, penelitian lain dari Zarowin menyatakan bahwa price reversal disebabkan oleh perbedaan ukuran perusahaan (firm size), berbeda dengan penelitian De Bondt dan Thaler yang mengungkapkan bahwa pembalikan harga tersebut terjadi karena adanya reaksi berlebihan dari pasar (market overreaction). Selain ukuran perusahaan (firm size), beberapa peneliti juga menemukan adanya faktor lain yang mempengaruhi pembalikan harga, di antaranya adalah bid-ask spread dan volume perdagangan. Adapun penelitian di Bursa Efek Indonesia (BEI) seperti yang dilakukan oleh Yull dan Kirmizi (2012) menjelaskan bahwa terjadi overreaction pada pembalikan harga (price reversal) saham perusahaan yang terdaftar di Bursa Efek Indonesia pada tahun 2007-2010, sementara bid-ask spread dan likuiditas saham tidak berpengaruh terhadap price reversal.

Tabel 1. Indeks Harga Saham Gabungan (IHSG) dan return pasar

\begin{tabular}{ccccr}
\hline Tanggal & Harga pembukaan (Rp) & Harga penutupan (Rp) & Perubahan harga (Rp) & Return pasar (\%) \\
\hline $11 / 8 / 2016$ & $5.407,38916$ & $5.470,68115$ & 63,2920 & 1,57 \\
$11 / 9 / 2016$ & $5.478,03418$ & $5.414,32080$ & $-63,7134$ & $-1,03$ \\
$11 / 10 / 2016$ & $5.444,04102$ & $5.450,30615$ & 6,2651 & 0,66 \\
$11 / 11 / 2016$ & $5.380,64111$ & $5.231,97119$ & $-148,6699$ & $-4,01$ \\
$11 / 14 / 2016$ & $5.194,92676$ & $5.115,73877$ & $-79,1880$ & $-2,22$ \\
$11 / 15 / 2016$ & $5.121,47803$ & $5.078,50098$ & $-42,9771$ & $-0,73$ \\
$11 / 16 / 2016$ & $5.112,49609$ & $5.185,46484$ & 72,9688 & 2,11 \\
\hline
\end{tabular}

Dari beberapa penelitian di atas, terdapat berbagai pendapat mengenai faktor-faktor seperti ukuran perusahaan, bid-ask spread, dan likuiditas saham yang berpengaruh terhadap fenomena price reversal serta mengindikasikan bahwa fenomena tersebut juga terjadi di Indonesia. Menurut data yang dikumpulkan melalui Indeks Harga Saham Gabungan (IHSG), terjadi perubahan harga saham yang kemudian diikuti oleh perubahan kembali ke arah yang berlawanan pada hari berikutnya. Fakta tersebut dapat dilihat pada Tabel 1 yang menampilkan hari perdagangan yang mengalami perubahan IHSG. Kenaikan dan penurunan harga saham ditentukan berdasarkan angka IHSG dengan melihat selisih harga pembukaan dan penutupan pada satu hari perdagangan. Perubahan harga dengan tanda positif menunjukan terjadinya kenaikan harga, sedangkan perubahan dengan tanda negatif menunjukan terjadinya penurunan harga. Perubahan indeks tersebut dikategorikan besar apabila return untuk kenaikan adalah lebih dari 2,5\% dan untuk penurunan lebih dari -2,5\%.

Berdasarkan fenomena yang terjadi pada Indeks Harga Saham Gabungan (IHSG) di atas, terjadi return pasar yang lebih kecil dari $-2,5 \%$, yaitu sebesar $-4,01 \%$ pada tanggal 11 November 2016, peneliti tertarik untuk melihat apakah fenomena tersebut memiliki pengaruh pada Indeks LQ45. Peneliti memilih Indeks LQ45 karena indeks tersebut terdiri dari 45 perusahaan dengan tingkat likuiditas yang tinggi dan kapitalisasi pasar yang besar, sehingga diharapkan dapat merepresentasikan keseluruhan perusahaan yang terdaftar di Bursa Efek Indonesia. Berdasarkan hasil penelitian yang telah dilakukan oleh peneliti sebelumnya dan fenomena yang terjadi, peneliti tertarik untuk meneliti adanya pengaruh ukuran perusahaan, bid-ask spread, dan volume perdagangan terhadap price reversal. Oleh karena itu, peneliti mengambil judul "Pengaruh Ukuran Perusahaan, Bid-Ask Spread, dan 
Volume Perdagangan terhadap Price Reversal". Terdapat tiga tujuan penelitian, yaitu untuk menganalisis pengaruh ukuran perusahaan, untuk menganalisis pengaruh bid-ask spread, dan untuk menganalisis pengaruh volume perdagangan terhadap price reversal perusahaan yang terdaftar pada indeks LQ45 di Bursa Efek Indonesia selama periode penelitian.

Hipotesis:

$\mathrm{H}_{1}$ : Ukuran perusahaan berpengaruh positif terhadap price reversal perusahaan Indeks LQ45 di Bursa Efek Indonesia tahun 2016.

$\mathrm{H}_{2}$ : Bid ask spread berpengaruh positif terhadap price reversal perusahaan Indeks LQ45 di Bursa Efek Indonesia tahun 2016.

$\mathrm{H}_{3}$ : Volume perdagangan berpengaruh positif terhadap price reversal perusahaan Indeks LQ45 di Bursa Efek Indonesia tahun 2016.

\section{TINJAUAN PUSTAKA}

Variabel penelitian ini terdiri dari dua macam variabel, yaitu variabel terikat dan variabel bebas. Variabel terikat pada penelitian ini adalah price reversal, sedangkan variabel bebas pada penelitian ini adalah ukuran perusahaan, bid ask spread, dan volume perdagangan. Price reversal merupakan perubahan harga saham karena investor telah melakukan kesalahan dalam menetapkan harga saham atau mispricing (Santosa, 2010). Menurut Jogiyanto (2008), variabel price reversal diwakili oleh cumulative abnormal return (CAR) sebagai berikut:

$$
\text { CAR i, } \mathrm{t}=\Sigma \text { ARi, } \mathrm{t}
$$

Ukuran perusahaan dapat menggunakan tolak ukur aset. Karena total aset perusahaan bernilai besar, maka hal ini dapat disederhanakan dengan mentranformasikan ke dalam logaritma natural (Ghozali, 2011) sebagai berikut:

$$
\text { Ukuran Perusahaan = Ln Total Assets }
$$

Bid-Ask Spread merupakan selisih dari harga beli tertinggi (bid price) dengan harga jual terendah (ask price) dari suatu saham pada satu hari perdagangan saham (Frijns et al., 2008). Variabel ini dihitung dengan relative bidask spread, sebagai berikut:

$$
\text { Relative bid }- \text { ask spread }=\frac{\mathrm{Ask}_{\mathrm{j} . \mathrm{t}}-\mathrm{Bid}_{\mathrm{j} . \mathrm{t}}}{\left(\mathrm{Ask}_{\mathrm{j} . \mathrm{t}}+\mathrm{Bid}_{\mathrm{j} . \mathrm{t}}\right) / 2}
$$

Volume perdagangan merupakan suatu instrumen yang digunakan untuk melihat reaksi pasar terhadap informasi yang beredar. Berikut merupakan perhitungannya:

$$
\text { Volume Perdagangan = Ln Volume Perdagangan }
$$

\section{METODE PENELITIAN}

Jenis data yang digunakan dalam penelitian ini adalah data sekunder yang berupa harga saham penutupan harian (closing price) harian Indeks Harga Saham Gabungan (IHSG), total aset, bid price, dan ask price serta volume perdagangan saham selama periode pengamatan. Sumber data diperoleh dari situs resmi Bursa Efek Indonesia (BEI) yaitu www.idx.co.id dan Yahoo Finance melalui www.finance.yahoo.com. Populasi dalam penelitian ini adalah perusahaan yang terdaftar pada Indeks LQ45 Bursa Efek Indonesia periode 2016. Sampel penelitian diambil menggunakan metode purposive sampling dengan kriteria: (1) terdaftar sebagai emiten di Bursa Efek Indonesia pada Indeks LQ45 periode Agustus 2016 - Januari 2017; (2) perusahaan tersebut memenuhi kelengkapan data selama periode penelitian seperti harga penutupan saham, IHSG harian, volume perdagangan, total aset, dan bid ask price; dan (3) aktif diperdagangkan selama periode penelitian yaitu pada tanggal 8 November - 16 November 2016 (kecuali tanggal 12-13 November 2016, karena hari libur Sabtu dan Minggu). Berdasarkan kriteria pemilihan sampel di atas, diperoleh jumlah sampel sebanyak 44 perusahaan yang memenuhi semua syarat penelitian untuk dijadikan sampel. 


\section{HASIL DAN PEMBAHASAN}

\section{Uji normalitas}

Uji normalitas bertujuan untuk menguji apakah nilai residual yang telah distandardisasi pada model regresi berdistribusi normal atau tidak (Suliyanto, 2011). Pengujian dengan metode Kolmogorov-Smirnov (uji K-S) dengan kriteria jika nilai Sig. $>\alpha(0,05)$, maka dapat disimpulkan bahwa data berdistribusi normal (Sugiyono, 2009). Berdasarkan hasil pengujian, terlihat bahwa nilai Sig. (2-tailed) sebesar 0,203 >0,05. Oleh sebab itu, dapat dikatakan bahwa nilai residual terstandardisasi menyebar secara normal atau dapat dikatakan bahwa data berdistribusi normal.

\section{Uji multikolinieritas}

Uji multikolinieritas bertujuan utnuk menguji apakah dalam model regresi yang terbentuk ada atau tidaknya hubungan linier antar variabel bebas. Penelitian ini menggunakan metode Variance Inflation Factor (VIF) dengan kriteria pengujian jika nilai VIF masing-masing variabel bebas $<10$ yang berarti model regresi tidak mengalami gejala multikolinieritas. Berikut hasil pengujian uji multikolinieritas:

Tabel 2. Hasil uji multikolinieritas

\begin{tabular}{lcc}
\hline Variabel & Nilai VIF & Keterangan \\
\hline BAS & 1.005 & Tidak ada multikolinieritas \\
VOL & 1.051 & Tidak ada multikolinieritas \\
UK & 1.049 & Tidak ada multikolinieritas \\
\hline
\end{tabular}

Berdasarkan output pada Tabel 2, terlihat bahwa nilai VIF masing-masing variabel ukuran perusahaan, bid ask spread, dan volume perdagangan $<10$ atau dapat disimpulkan bahwa tidak terdapat gejala multikolinieritas di antara variabel bebas pada model regresi tersebut.

\section{Uji heteroskedastisitas}

Uji heteroskedastisitas bertujuan untuk menguji apakah dalam model regresi terjadi ketidaksamaan varians dan residual suatu pengamatan ke pengamatan lain. Dengan menggunakan metode Glesjer, jika Sig. > 0,05, maka model regresi tidak mengalami gejala heteroskedastisitas. Pada penelitian ini, nilai probabilitas untuk ukuran perusahaansebesar $0,226>0,05$, bid ask spread sebesar 0,266 >0,05, dan volume perdagangan sebesar 0,241> 0,05 , maka dapat disimpulkan model tidak mengalami gejala heteroskedastisitas.

\section{Uji autokorelasi}

Uji otokorelasi digunakan untuk melihat apakah ada korelasi antara anggota serangkaian data observasi diuraikan menurut waktu (time series) dan ruang (cross section). Uji autokorelasi pada penelitian ini menggunakan metode run test dengan hasil nilai Sig. 0,07 >0,05, maka dapat disimpulkan bahwa model tidak mengandung gejala autokorelasi.

Tabel 3. Hasil uji heteroskedastisitas

\begin{tabular}{clccccc}
\hline Model & & B & Std. eror & Beta & t & Sig. \\
\hline \multirow{2}{*}{1} & (Constant) & 0,538 & 0,221 & & 2,429 & 0,016 \\
& BAS & $-0,090$ & 0,074 & $-0,092$ & $-1,215$ & 0,226 \\
& VOL & $-0,008$ & 0,007 & $-0,086$ & $-1,115$ & 0,266 \\
& UK & $-0,010$ & 0,008 & $-0,091$ & $-1,176$ & 0,241 \\
\hline
\end{tabular}

Tabel 4. Hasil uji $\mathrm{t}$

\begin{tabular}{lccccc}
\hline Variabel & thitung $_{\text {nabel }}$ & t $_{\text {tabel }}$ & Sig. & Alpha $(\alpha)$ & Pengaruh \\
\hline Ukuran perusahaan & 17,804 & 1,681 & 0,00 & 0,05 & Positif signifikan \\
Bid-ask spread & 3,766 & 1,681 & 0,00 & 0,05 & Positif signifikan \\
Volume perdagangan & 25,566 & 1,681 & 0,00 & 0,05 & Positif signifikan \\
\hline
\end{tabular}

\section{Pengujian hipotesis}

Uji F digunakan untuk mengetahui secara bersama-sama apakah variabel bebas berpengaruh secara signifikan atau tidak terhadap variabel terikat (Ghozali, 2011). Kriteria pengujian apabila nilai Sig. $<0,05$ atau nilai Fhitung $>$ $\mathrm{F}_{\text {tabel, }}$ maka dapat disimpulkan bahwa variabel bebas secara simultan berpengaruh terhadap variabel terikat. Hasil 
pengujian menunjukan nilai Sig. 0,000 $<0,05$ dan nilai $F_{\text {hitung }} 26,369>F_{\text {tabel }}$ 9,277, maka dapat dikatakan variabel ukuran perusahaan, bid ask spread, dan volume perdagangan secara bersama-sama berpengaruh terhadap price reversal atau model fit. Koefisien determinasi digunakan untuk mengukur seberapa jauh kemampuan variabel independen dalam menerangkan variasi variabel dependen. Berdasarkan hasil tersebut, dapat dilihat bahwa besar adjusted $\mathrm{R}^{2}$ adalah sebesar 0,206. Artinya, variabel ukuran perusahaan, bid ask spread, dan volume perdagangan mempengaruhi price reversal sebesar 20,6\% dan sisanya sebesar 79,4\% dipengaruhi oleh variabel lain yang tidak diteliti. Pengujian hipotesis secara parsial menggunakan thitung. Nilai thitung digunakan untuk menguji apakah variabel independen berpengaruh secara signifikan terhadap variabel dependen atau tidak. Nilai tabel pada penelitian ini adalah sebesar 1,668 yang didapatkan dengan tingkat kesalahan $(\alpha)=0,05$.

Hasil penelitian menunjukan nilai thitung $(17,804)>t_{\text {tabel }}(1,681)$ dan signifikansi $(0,000)<\alpha(0,05)$, maka dapat disimpulkan ukuran perusahaan secara parsial berpengaruh positif dan signifikan terhadap price reversal. Sehingga hipotesis pertama $\left(\mathrm{H}_{1}\right)$ yang menyatakan bahwa ukuran perusahaan berpengaruh positif terhadap price reversal diterima. Hasil penelitian menunjukan nilai thitung $(3,766)>t_{\text {tabel }}(1,681)$ dan signifikansi $(0,000)<\alpha$ $(0,05)$, maka dapat disimpulkan bid ask spread secara parsial berpengaruh positif dan signifikan terhadap price reversal. Sehingga hipotesis kedua $\left(\mathrm{H}_{2}\right)$ yang menyatakan bahwa bid ask spread berpengaruh positif terhadap price reversal diterima. Hasil penelitian menunjukan nilai thitung $(25,566)>t_{\text {tabel }}(1,681)$ dan signifikansi $(0,000)<\alpha$ $(0,05)$, maka dapat disimpulkan volume perdagangan berpengaruh positif dan signifikan terhadap price reversal. Sehingga hipotesis ketiga $\left(\mathrm{H}_{3}\right)$ yang menyatakan bahwa volume perdagangan berpengaruh positif terhadap price reversal diterima.

\section{KESIMPULAN}

Berdasarkan hasil analisis dan pembahasan mengenai analisis pengaruh ukuran perusahaan, bid ask spread, dan volume perdagangan terhadap price reversal, dapat disimpulkan bahwa: (1) ukuran perusahaan berpengaruh positif dan signifikan terhadap price reversal pada perusahaan yang terdaftar di Indeks LQ45 Bursa Efek Indonesia selama periode penelitian; (2) bid ask spread berpengaruh positif dan signifikan terhadap price reversal pada perusahaan yang terdaftar di Indeks LQ45 Bursa Efek Indonesia selama periode penelitian; dan (3) volume perdagangan berpengaruh positif dan signifikan terhadap price reversal pada perusahaan yang terdaftar di Indeks LQ45 Bursa Efek Indonesia selama periode penelitian. Implikasi atau saran sehubungan dengan hasil penelitian ini adalah investor dapat memperhatikan faktor ukuran perusahaan, bid ask spread, dan volume perdagangan sebagai dasar pertimbangan untuk melakukan trading di bursa, sehingga dapat memperoleh harga yang sesuai dengan kompensasi risiko yang diterima.

\section{DAFTAR PUSTAKA}

Frijns, B., Gilbert, A., dan Tourani-Rad, A. (2008). Insider trading, regulation, and the components of the bid-ask spread. The Journal of Financial Research, 31(3), 225-246.

Cleary, S. dan Jones, J.P. (2011). Investments: analysis and management. USA: Wiley.

Ghozali, I. (2011). Aplikasi analisis multivariate dengan program IBM SPSS 19 (edisi kelima). Semarang: Universitas Diponegoro.

Jogiyanto, H.M. (2008). Teori portofolio dan analisis investasi (edisi ketiga). Yogyakarta: Badan Penerbit Fakultas Ekonomi Universitas Gadjah Mada.

Santosa, P.W. (2010). Memahami overreaction di pasar modal.

Sugiyono. (2009). Metode penelitian bisnis. Bandung: Alfabeta.

Suliyanto. (2011). Ekonometrika terapan: Teori \& aplikasi dengan SPSS. Yogyakarta: Andi Offset.

Susilawati, R.A.E. (2009). Reaksi pasar modal terhadap pengumuman stock split: Studi pada perusahaan LQ 45 di Bursa Efek Indonesia. Jurnal Ekonomi Modernisasi, 5(1).

Tandelilin, E. (2010). Portofolio dan investasi teori dan aplikasi (edisi pertama). Yogyakarta: Kanisius.

Yull, E. dan Kirmizi. (2012). Analisis overreaction hypothesis dan pengaruh ukuran perusahaan, bid-ask spread, dan likuiditas saham terhadap fenomena price reversal: Studi empiris pada perusahaan yang terdaftar di BEI. Jurnal Pendidikan Ekonomi dan Bisnis, 4(1), 1-16. 